\title{
Evaluation of bioconcentration of trace elements in the Western Mediterranean mouse (Mus spretus Lataste, 1883) at two Moroccan wetland sites
}

LOUBNA tifarouine ( $\sim$ loubna.tifarouine@um5s.net.ma )

Mohammed V University of Rabat: Universite Mohammed V de Rabat https://orcid.org/0000-00019449-677X

Asmae Benabbou

Mohammed V University of Rabat: Universite Mohammed V de Rabat

Hamid Rguibi Idrissi

Mohammed V University of Rabat: Universite Mohammed V de Rabat

Abdelaziz Benhoussa

Mohammed V University of Rabat: Universite Mohammed V de Rabat

\section{Research Article}

Keywords: biomonitoring, Mus spretus, bioindicator, trace elements, Morocco, Merja Zerga, Dayet Erroumi

Posted Date: April 1st, 2021

DOI: https://doi.org/10.21203/rs.3.rs-367148/v1

License: (c) (i) This work is licensed under a Creative Commons Attribution 4.0 International License. Read Full License 


\section{Abstract}

Many micromammals were shown to be vulnerable to metallic trace elements and are therefore suitable for biomonitoring. The objective of our research is to assess the exposure of a small rodent, Mus spretus, as a bioindicator of pollution to trace elements. We have determined the concentrations of $\mathrm{Cu}, \mathrm{Pb}, \mathrm{Cr}, \mathrm{Zn}$ and Fe in the liver, kidneys and heart of 71 individuals of Mus spretus in north-west Morocco in two areas: Merja Zerga and Dayet Erroumi. Tissue metal concentrations in this species varied widely with age, sex, sites and organs. The concentration of $\mathrm{Cu}$ in the liver was the highest among all the metals and was recorded in adult females of Merja Zerga with a maximum of $60 \mu \mathrm{g} / \mathrm{g}$; at Dayet Erroumi, it was around $14 \mathrm{\mu g} / \mathrm{g}$. At the same time, we found a similar trend for $\mathrm{Fe}, \mathrm{Pb}, \mathrm{Cr}$ and $\mathrm{Zn}$ in the three organs in males and females at the two sites. Highly significant differences between females at the two sites were recorded for the variables weight $(W)$ and head to body length $(T L)(t=-3.992 ; p<0.001$ and $t=-2.242, p$ $<0.05)$, however, males obtained equal values in the two sites. Spatiotemporal monitoring in small mammals must be studied, but requires the application of a non-lethal estimator.

\section{Introduction}

Metallic pollution occupies a prominent place among the various processes of anthropogenic disturbances that affect the normal course of living systems. Contrary to organic pollution, contamination by metallic trace elements poses a serious environmental problem because it accumulates and can persist for a long time in the soil (Alimohammad Kalhori et al, 2012; Ashraf et al, 2012; Okuku and Peter, 2012) which constitutes a real threat to human health (Fritsch et al 2010; Mzoughi and Chouba 2012; Ghaderi et al 2012; Slavka Stankovic et al, 2014; Benabbou et al, 2015). Living organisms need specific concentrations of essential metallic elements, such as iron (Fe) and zinc $(\mathrm{Zn})$, but they can be toxic to the body in highlevels. Other non-essential metals such as lead $(\mathrm{Pb})$, cadmium (Cd) and chromium $(\mathrm{Cr})$ that exceed the allowed thresholds interfere with the normal functioning of biological processes. These metallic elements can enter the body of living organisms at all stages of development (Ogundiran et al, 2008; Serbaji et al, 2012).

Numerous studies have investigated the heavy metal contamination in micromammals. The measuring of heavy metals concentrations in the target organs of small wild mammals can reveal the high levels of these metals in the environment. In fact, that can be explained by environmental pollution, additionally metals residues in the soil and the organs or tissues of the body were noteworthy related (Tête et al, 2014). Indeed, studies made in different regions of several countries affirmed that small terrestrial mammals bioaccumulate heavy metals in their tissues (Metcheva et al, 2002; leradi et al, 2003; Blagojević et al, 2012; Tête et al, 2014) and several species have been proposed as promising indicators for estimating the risks of pollution by heavy metals.

The anthropized areas and agro-ecosystems in Morocco are occupied by various micromammals, especially Murid rodents from the genera Gerbillus, Meriones, Rattus and Mus (Bouarakia et al, 2019). Apart from the studies carried out by Tifarouine et al, $(2018 ; 2019)$, no information concerning metal 
contamination of small mammals (rodents) in Moroccan agricultural fields is available. In addition to laboratory analysis, rodents constitute a real model to understand the effects of in situ metallic contaminants. Furthermore, the behavior and distribution of heavy metals in their tissues is similar to that of humans (Damek-Poprawa M et al, 2003).

The main objective of this study is to evaluate the bioconcentration of five trace elements $(\mathrm{Cu}, \mathrm{Pb}, \mathrm{Cr}, \mathrm{Fe}$ and $\mathrm{Zn}$ ) in rodents at two sites of major interest for Moroccan biodiversity; Dayet Erroumi and Merja Zerga that are threatened by the massive use of fertilizers. The North African Mouse, Mus spretus Lataste 1883 , has been used as a bioindicator to assess the potential risk of exposure to heavy metals (GarciaSevillano M.A. et al, 2014; Quina A.S. et al, 2019). This small rodent is found in North Africa, as well as in the Iberian Peninsula and the south of France. In Morocco, it is present in all regions of plains and hills outside of the Sahara Desert; and it occupies a wide range of environments (crops, yards, juniperaies, mixed oak forests, etc.). It is a nocturnal and opportunist species, feeding mainly on grass seeds, fruits and sometimes insects (Aulagnier et al. 2017).

\section{Material And Methods}

\section{Study sites}

This study was realised in two areas (Fig.1) characterized by intense activities in terms of fishing, farming and strong urbanization:

Merja Zerga, located in the northwest of Morocco $\left(34^{\circ} 47^{\prime} \mathrm{N}, 6^{\circ} 13^{\prime} \mathrm{W}\right)$, covers an area of $30 \mathrm{~km}^{2}$, with a maximum length of $9 \mathrm{~km}$ and a maximum width of $5 \mathrm{~km}$. It is divided into two areas of unequal surface area and importance (the Merja Kahla of $3 \mathrm{~km}^{2}$ and Merja Zerga of $27 \mathrm{~km}^{2}$ ). In addition to its tidal inflow, the lagoon system receives drainage mainly from the Drader River to the east and from the Nador Canal to the south.

This paralic site is one of the first four sites on the Ramsar List, recognized world wide for its biological diversity (Benhoussa et al, 1999; Bazaïri et al. 2003; Maanane et al, 2013; Ainou, 2016; Touhami et al, 2018), it is an important wintering and migratory stopover site for waterbirds (Qninba et al, 2006;

Cherkaoui and Lamrani 2007; Touhami et al,2018). Agricultural activity is very developed on the site and uses a lot of fertilizers and phytosanitary products.

Dayet Erroumi is located $15 \mathrm{~km}$ from Khemisset $\left(33^{\circ} 45^{\prime} \mathrm{N}\right.$ and $\left.6^{\circ} 12^{\prime} \mathrm{W}\right)$, classified as a site of biological and ecological interest of Morocco. It is a nearly 96 ha shallow lake (14 m maximum) characterized by a semi-arid climate and a Mediterranean rainfall pattern (Bounif I. et al, 2017). The lake is fed by groundwater and a stream from the southeast. To the northeast, a platform corresponding to the outlet of the lake makes the junction between the lake and a permanent stream (Oued Rehhou). At the northeast end of the lake, opens a drainage channel of a marshy depression located 1-2 km northeast of the lake.

\section{Sampling sites}


Sampling was done at night with Sherman traps, baited with a mixture of peanut butter, olive and bread. 100 traps are deposited along transects of six hectares. Catches were made in trapping sessions of five nights per site. A total of 71 specimens of Mus spretus were collected, including 25 males, 14 females captured at Merja Zerga and 12 males, 20 females sampled at Dayet Erroumi. The poor capture yield could be attributed to poor climatic conditions during trapping (wind, cold) as well as a limited number of traps and heavy site traffic. We note that these small mammals are herbivorous and have nocturnal activity. All captured individuals were weighed (W), measured head to body length (TL), ear length $(E)$, and posterior leg length $(\mathrm{PL})$ ) and sacrificed by chloroform inhalation. After that, their organs (liver, kidney and heart) were extracted and maintained at $-18 \mathrm{C}^{\circ}$ until further analysis.

\section{Metal analysis}

The collected organs are weighed before being hot-mineralized at $120^{\circ} \mathrm{C}$ for 4 hours according to a process of the accredited toxicology laboratory at the National Institute of Hygiene (INHRabat, Morocco). Metal elements contained in the three organs were found out by the mineralizations after dilution. The $\mathrm{Pb}$, $\mathrm{Cu}$ and $\mathrm{Cr}$ concentrations were determined by atomic absorption spectroscopy with a graphite furnace (Varian AA 240120 GTA Z) (Chiffoleau and Truquet, 1994), the background correction is made by a Zeeman effect. Fe and $\mathrm{Zn}$ contents were determined by flame atomic absorption spectroscopy (VARIAN AA40 FS). To reduce the chemical interference and volatility of $\mathrm{Cr}$, $\mathrm{Cu}$ and $\mathrm{Pb}$ in an oven, a matrix modifier is used (mixture of $\mathrm{PdCl} 2$ and $\mathrm{MgNO}$ ). The calibration curve was generated by the "MSA (standard addition method)". The validity of this method is verified by internal control using standard samples (National Research Council of Canada: DORM-2) and by external control using intercalibration exercises (IAEA-MESL -2014-01-TE) which uses blood doping samples. After the linearity of the curve, the accuracy was checked by three successive readings for each sample, the average of these measurements would be taken into consideration if the RSD (relative standard deviation) was less than $10 \%$.

\section{Statistical methods}

From each tissue, an overall measure of gender, age, and site effect on metal concentrations was obtained by a four-way multivariate analysis of variance (MANOVA). The normality and variances homogeneity of the aforementioned variables were checked. The differences were considered statistically significant at $\mathrm{p}$-value $\leq 0.05$. All the statistical analyzes were performed by $\mathrm{R}$ software using FactoMiner, Factoextra, ggplot2 and corrplot packages.

\section{Results}

\section{Morphological characterization}

A total of 35 individuals were captured at Merja Zerga and 32 specimens at Dayet Erroumi. Males dominate at the Merja Zerga with 25 individuals, while females are more abundant at Dayet Erroumi (Table 1). It must also be noted that the proportions of juveniles are larger in the Merja Zerga sample than in the Dayet Erroumi sample, with respectively $46.15 \%$ and $21.87 \%$ males of the total catches in each site. 
The comparative analysis of the morphometric characters (Weight (W), head to body length (TL), ear length $(E)$, and posterior leg length $(P L))$ of the population of the Merja Zerga lagoon and that of Dayet Erroumi exhibits that the highest value for weight is recorded in Dayet Erroumi females with a maximum of $19.2 \mathrm{~g}$ followed by Merja Zerga males with a value of $17 \mathrm{~g}$ (Fig.2). The females of Dayet Erroumi have also larger sizes with TL values of around $95 \mathrm{~mm}$, followed closely by Merja Zerga females which recorded TL values of $92 \mathrm{~mm}$. The males of both sites have comparable sizes with TL values reaching $89 \mathrm{~mm}$. The other two characters, length of the ear $(E)$ and length of the hind legs $(P L)$ showed comparable values in both sexes of the two populations.

Females got higher wheight than males in Dayet Erroumi $(t=-3.315$ and $p<0.001)$. When comparing females between the two sites, we found that Dayet Erroumi females got higher $W$ and $T L(t=-3.992 ; p$ $<0.001$ and $t=-2.242, p<0.05)$, however, males got equal values in the sites. Males and females from Merja Zerga have equal morphological variables.

\section{Elemental concentrations}

The concentrations of several elements in the studied Mus spretus varied between tissues and sexes at each capture site (see Figure 3). In Dayet Erroumi, liver tissue had higher concentrations, followed by kidney and heart. The accumulation of metals in females was very high compared to males, with a maximum reaching $13.65 \mu \mathrm{g} / \mathrm{g}$ for the $\mathrm{Cu}$, followed by the $\mathrm{Pb}$ at $12.34 \mu \mathrm{g} / \mathrm{g}$. In Merja Zerga, the highest levels of $\mathrm{Cu}$ and $\mathrm{Cr}$ liver were recorded in females with a maximum of $60 \mu \mathrm{g} / \mathrm{g}$ and $28.68 \mu \mathrm{g} / \mathrm{g}$ successively. A similar trend was revealed for $\mathrm{Fe}, \mathrm{Pb}$ and $\mathrm{Zn}$ in all three organs in both sexes.

In all the organs, males of Meja Zerga exceeded those of Dayet Erroumi for the majority of heavy metals. Females from both sites showed significant differences for $\mathrm{Zn}, \mathrm{Cu}$, and Fe. While the liver harbored the five element traces, the heart bioccumulates $\mathrm{Zn}, \mathrm{Cr}, \mathrm{Cu}, \mathrm{Pb}$ and kidneys concentrated just $\mathrm{Zn}, \mathrm{Cr}$, and $\mathrm{Cu}$.

To analyse the effect of sex, site, age and organs on metal concentrations, MANOVA for all data showed that $\mathrm{Zn}$ and $\mathrm{Cu}$ concentrations were significantly affected by all variables. $\mathrm{Pb}$ was affected only by organs and sex, $\mathrm{Cr}$ was affected by age and Fe was affected with all variables except site.

The pattern of metal accumulation by tissues was similar at both sites. The liver was the main target organ of the five trace elements examined $(\mathrm{Zn}, \mathrm{Cr}, \mathrm{Cu}, \mathrm{Fe}$ and $\mathrm{Pb})$. Indeed, the concentrations of their majority there were the highest, which implied that an examination of the liver was also important.

The second axis $\mathrm{F} 2$ ( $15.6 \%$ of total inertia) is determined by the concentration of $\mathrm{Cr}$, as the dominant element, in the various organs analyzed and which follows the order of importance according to $\mathrm{KCr}>$ $\mathrm{HCr}>\mathrm{LZn}$.

On the scatter diagram of the first two axes of the PCA (Fig. 4.b) we can distinguish two main groups:

- Group 1: present on the positive side of the F1 axis the majority of adults of the species Mus spretus from the two areas studied. It is characterized by high contents of Zn, Fe and Cu followed by average 
contents of $\mathrm{Pb}$ and $\mathrm{Cr}$, thus a large size (W, PL, TL and $\mathrm{E})$. This confirms the existence of an increasing gradient in size and clear HMs concentrations demonstrated by the main component (PCA).

- Group 2: groups the juveniles of the species studied on the negative side. It indicates a weak presence of $\mathrm{HMs}$ in the three tissues analyzed and a small size.

The PCA dispersion diagram (Fig. 4.C) allows you to view four groups and indicates a well-defined accumulation by area and sex, as evidenced by the respective overlapping of the following groups:

- $\mathrm{A}$ and $\mathrm{B}$, grouping the males and the females of Merja Zerga with significant contents in $\mathrm{Cu}, \mathrm{Cr}$ and $\mathrm{Pb}$.

- And groups $C$ and $D$ unify males and females of the Dayet Erroumi with a fairly large size in females and average concentrations of HMs (Fig.4.C).

We also verify the correlation between the various morphometric parameters and the rates of accumulation of HMs in their studied organs and we give a synthetic measure of the intensity of the relationship between these characters and of their senses (Fig. 5).

The correlation matrix indicates and confirms an accumulation in synergy between several couples, notably Zn/Cr, Zn-Fe and Cu-Zn. Strong significant correlations $(\mathrm{p}<0.05)$ were observed between LZnKZn, LZn-HZn, KZn-HZn, LFe-KFe, KFe-HFe and LFe-HFe $(0.76<r<0.94)$, means between KCr-HCr, LCuKCu, KPb-HPb, LCu-HZn, LCu-KZn, LZn-LCu, LZn-KFe, TL-LZn and PL-E $(0.43<r<0.75)$.

\section{Discussion}

\section{Bioaccumulation of metals by site}

Metal pollution is a growing environmental problem that requires constant attention (Nasrabadi et al, 2010; Sambo et al, 2014; Lai et al, 2010; Kargar et al, 2012). As one of the main groups of pollutants, they are not biodegradable and can persist for a long time in soil, water and sediment (Xiaoyu Li et al, 2012; Okuku and Peter, 2012). They can also bioaccumulate and biomagnify along the food chain (Farag et al, 2012). The results we obtained showed highly significant differences in the bioaccumulation of nonessential elements $(\mathrm{Cu}, \mathrm{Cr}$ and $\mathrm{Pb}$ ) by site. The Musspretus of the Merja Zerga have accumulated twice the $\mathrm{Cu}, \mathrm{Cr}$ and $\mathrm{Pb}$ compared to those of the Dayet Erroumi. The high concentrations of trace elements reported at the Merja Zerga are the result of pollution whose origin is different. The concentrations are mainly due to the discharges of the exhausts of the vehicles and the wear of the tires containing the Lead (Blagojevic $\mathrm{J}$ et al, 2012), because this zone is known by a very dense road traffic (Tifarouine et al, 2019). Merja Zerga is positioned on two large agricultural perimeters: Gharb and Loukkos. The Gharb plain is one of the most important agricultural production areas in Morocco (ORMVAG 2010). Concurrently, Loukkos covers a large agricultural area nationally; principally it provides $80 \%$ of strawberry's production, rice, peanuts (20\%) and sugar crops (15\%). Generally, these crops consume a lot of pesticides. According to ORMVAG 2007, 12 pesticide residues were recorded at the Gharb perimeter of water and soil resources, which may lead to a subsequent accumulation of specific elements, in particular $\mathrm{Cu}$ and $\mathrm{Zn}$ in the soil 
(Abt KF, 1998). We recall also that measurements of the $\mathrm{Pb}$ concentration using a sampler placed directly in the middle of the fumes emerging from the chimneys of the city of Rabat, have shown $\mathrm{Pb}$ concentrations exceeding $1000 \mu \mathrm{g} / \mathrm{m} 3$ (El Abidi et al, 2000). Lee (2007) approved the long-range possibility of the fallout of airborne dust from large industrial cities, bordering the Merja Zerga such as Rabat, Kenitra, and Larache. Similarly, according to several authors, climatic conditions (temperature and wind) have a remarkable effect on seasonal variation in air pollution (Aunan et al, 2006; Ding et al, 2013; Wang et al, 2018). The low Dayet Erroumi levels are caused by the lack of a significant influence of the two origines of pollution mentioned above, since the sampling site is about $80 \mathrm{~km}$ away from these emissions.

\section{Bioaccumulation of trace elements by age and sex}

Micromammals are widely distributed in the world, which makes them a good model for studying pollution effects. The wide range of variation observed in the two areas can be explained in part by factors (biotic and abiotic) that may influence their level of exposure to xenobiotics such as the duration of exposure to pollutants, the properties of the element, the diet and, consequently, the individual response to the absorption and bioaccumulation of metals, the physiology of the population including size, sex and age is also added (Beernaert et al, 2008; Rautio et al, 2010). Generally, when a living organism is exposed to metals, it can penetrate into all stages of development (Ogundiran et al, 2008; Serbaji et al, 2012). In the case of variation in the concentration of essential metals, these may be related to the life cycle (growth requirements, gonad maturation and reproduction) (Lopes et al, 2002; Udroiu et al, 2008). Our results presented that heavy metals accumulation in tissues of adult females of Mus spretus approximately three times higher than those of female juveniles. The high Cu concentration was found in adult females from Merja Zerga with a maximum of $60 \mu \mathrm{g} / \mathrm{g}$; while at Dayet Erroumi, it is around $14 \mu \mathrm{g} / \mathrm{g}$. This metal is an essential element in humans and animals and is of paramount importance in the maintenance of biological processes, particularly for hemoglobin formation and the maturation of neutrophils. It is also known for its fungicidal effect on plants, is present in the receiving aquatic ecosystem and can cause disturbances in phytoplankton populations (Pesce S., 2006). At the same time, $\mathrm{Cr}$ and $\mathrm{Pb}$ increased with age in female Mus spretus with a maximum of $28.68 \mu \mathrm{g} / \mathrm{g}$ at Merja Zerga and $12.34 \mathrm{\mu g} / \mathrm{g}$ at Dayet Erroumi. The presence of higher trace element concentrations in adult females may be attributed to both elevated metabolic rate and disruption of toxic metal neutralization mechanisms (Kljaković Gašpić et al, 2002), therefore the nutritional status and physiological needs of individuals lead to intra-population variances in heavy metals accumulation. The increase in concentrations of the HMs in Merja Zerga matches the preceding studies reporting significant amounts of these elements in the soil (Mhamdi Alaoui et al, 2010 ; Maanane et al, 2015; Boutahar et al, 2019), in fish (Wariaghli et al, 2013) and in rodent tissues (Tifarouine et al, 2018). Tifarouine et al, 2019; reported that the effectiveness of the bioaccumulation process of Apodemus sylvaticus (Muridae) in Merja Zerga depends only on the individual's age whereas sex has no effect. Sanchez Cardi et al, 2007, demonstrated that mercury increase with age also occurs in another micromammal, Crossidura russula from a polluted wetland. In contrast, the present study has demonstrated that bioaccumulation of HMs in Mus spretus depends both on age and on sex. 


\section{Bioaccumulation of trace elements by tissues}

Trace elements are necessary for terrestrial and aquatic organisms, such as $\mathrm{Cu}, \mathrm{Cr}$, Fe and $\mathrm{Zn}$. For some organisms, minute amounts of these elements are essential for normal growth and development. However, at high levels of exposure and adsorption, these elements can be potentially harmful to most organisms (Yorulmaz et al, 2015). The kidneys and the liver are the key organs, when it comes to metabolic pathways involving metals, like bioaccumulation, biotransformation, excretion and detoxification (Dragun et al, 2009; Sunjog et al, 2012). Once micronutrients cross biological barriers and enter the bloodstream, they reach the liver and accumulate there. Our results on the distribution of metals in Mus spretus correspond to those reported for other mammalian species (Gdula-Argasińska et al, 2005; Jarić et al, 2011; Tête N et al, 2014; Prevendar Crnić et al, 2015; Gašparík et al, 2016; Zietara et al, 2018). The liver was the main accumulator of the five elements studied in both sites, followed by the kidney and heart. The hepatic concentration in females of Merja Zerga was higher than in males with a maximum of $60 \mu \mathrm{g} / \mathrm{g}$ for Cu and $28.68 \mu \mathrm{g} / \mathrm{g}$ for Cr. The same distribution was recorded at Dayet Erroumi with 13.65 $\mu \mathrm{g} / \mathrm{g}$ for $\mathrm{Cu}$ and $12.34 \mu \mathrm{g} / \mathrm{g}$ for $\mathrm{Pb}$. This tissue distribution corroborates the results obtained for Apodemus sylvaticus in Merja Zerga (Tifarouine et al. 2019), and Crocidura leucodon (Marques, 2007).

\section{Conclusion}

The present study provides original results on concentrations of numerous trace elements in the liver, kidney and heart of the rodent Mus spretus in Northern Morocco. We have found that the bioaccumulation of some metals in the organs is a process whose effectiveness depends on sex, individual age, and habitat. In Merja Zerga, concentrations of these elements in adults were two to three times higher than in Dayet Erroumi. A possible cause could be higher metal pollution levels in Merja Zerga. The accumulation process continues throughout their life, although these older micromammals have a lower rate of metabolism, so the accumulation of trace elements directly depends on the level of pollution. According to our results, a difference between the two localities can only be clearly observed in older individuals, so this category should be the target of further studies.

\section{Declarations}

\section{Conflict of interest statement}

On behalf of all authors, the corresponding author states that their is no conflict of interest.

\section{Acknowledgements}

The present study was supported by the Laboratory 'Biodiversity, Ecology and Genome' of the Faculty of Sciences of Rabat, we wish to express our gratitude to Pr. Bouabid Badaoui for their help and scientific suggestions. We also thank Oussama Bouarakia for helping in the field work.

\section{Author agreement statement \& Authors Contributions}


We would like to present our manuscript " The Western Mediterranean mouse (Mus spretus: Lataste): Capacity of accumulation and biomonitoring of trace elements in Atlantic wetlands." It has not been published before and is not currently being considered for any publication elsewhere.

We confirm that this manuscript has been read and approved by all named authors. We would also like to confirm that the order of authors listed in the manuscript has been approved by all of us.

The main objective of this research was to assess the exposure of Mus spretus to the five metallic trace elements in their vital organs in two zones: Merja Zerga and Dayet Erroumi classified successively, Ramsar site and SIBE in northern Morocco. Tissue metal concentrations in this species varied significantly with age, sex, site and organ.

I have read positive comments on your review and the variety of fields and subjects it covers and publishes; particularly, in the area of ecotoxicology, environmental safety and bioremediation, as well as the conservation of biodiversity.

We have chosen: MOHAMED Abdel Daim, Muhammad Ajmal Shah and Jauad El Kharraz as international experts in ecotoxicology, conservation and biodiversity to evaluate and review our document.

Finally, we understand that the Corresponding Author is the sole contact for the Editorial process. He is responsible for communicating with the other authors about progress, submissions of revisions and final approval of proofs.

\section{Funding}

This research was supported and funded by the Laboratory 'Biodiversity, Ecology and Genome' under the supervision of Professor Abdelaziz BENHOUSSA.

\section{References}

Abt K.F. ; Bock W.F. (1998). Seasonal variations of diet composition in farmland field mice Apodemus spp. And bank voles Clethrionomys glareolus. Acta Theriologica. 43 (4) 379-389.

Ainou H. (2016). Etude des habitats de la lagune de Moulay Bousselham et actualisation de leur cartographie. Projet de fin d'étude de Master, Université Mohamed V, Rabat.

AlimohammadKalhori A ., Jafari H. R. , Yavari A. R., Prohić E. and AhmadzadehKokya T., (2012). Evaluation of Anthropogenic Impacts on Soiland Regolith Materials Based on BCR Sequential Extraction Analysis. Int. J. Environ. Res., 6 (1):185-194.

Ashraf M.A., Maah M.J., \& Yusoff I. (2012). Bioaccumulation of heavy metals in fish species collected fom former tin mining catchment. Int. J. Environ. Res., 6(1):209-218. 
Aulagnier S., Cuzin F., Thévenot M. (2017). Mammifères sauvages du Maroc : Peuplement, répartition, écologie, Soc. Franc. Etude et Protection des Mammifères.

Aunan K, Fang JH, Hu T, Seip HM, Vennemo H. (2006). Climate change and air quality - Measures with co-benefits in China. Environ SciTechnol. 40:4822-4829.

Bazaïri H., Bayed A., Glemarec M. and Hily C., (2003). Spatial organisation of macrozoobenthic communities in response to environmental factors in a coastal lagoon of the NW African coast (Merja Zerga, Morocco). Oceanologica Acta. 26, 457-471.

Beernaert, J., Scheirs, J., Van Den Brande, G., Leirs, H., Blust, R., De Meulenaer, B., Van Camp, J. and Verhagen, R., (2008). Do wood mice (ApodemussylvaticusL.) use food selection as a means to reduce heavy metal intake?. Environ. Pollut. 151 (3), 599-607.

Benabbou A., Benhoussa A., Fekhaoui M., El blidi S., El Abidi A.and Bounagua M. (2015).Application of Multivariate Statistical and Geochemical methods for assessing of Groundwater pollution near controlled Landfill in OumAzza area, NW Morocco. Int. Res. J. of Earth Sciences, Vol. 3(3):9-14.

Benabbou A., Benhoussa A., Fekhaoui M., Elblidi S., ElAbidi A., Bounagua M. (2014). Assessment the risk of impact of waste treatment center on groundwater quality in Oum Azza (Rabat, Morocco). J. Mater. Environ. Sci. 5(1):143-152.

Benhoussa A., Dakki M., Qninba A. \& EL Agbani M.A. (1999). Habitats d'un site Ramsar côtier du Maroc, la Merja Zerga: approches typologique et cartographique. Humedales Mediterràneos. 1: 75-82.

Blagojevic J., Jovanovic V., Stamenkovic G., Jojic V., Bugarski-Stanojevic V., Adnadevic T., et al., (2012). Age differences in bioaccumulation of heavy metals in populations of the black-striped field mouse, Apodemus agrarius (Rodentia, Mammalia). Int J .Environ .Res. 6:1045-1052.

Bouarakia O., Denys C., Nicolas V., Benazzou T. \& Benhoussa A. (2019). Biogeographic history of Gerbillus campestris (Rodentia, Muridae) in Morocco as revealed by morphometric and genetic data. Bonn zoological Bulletin. 68(1): 97-124.

Bounif I., Taouil H., Elanza S., Ibn Ahmed S. \& Aboulouafa M. (2017). Physicochemical study of Dayet ErRomi Lake water, Khemisset region. American journal Of Engineering Research.6 (3):101-106.

Boutahar L., Maanan M., Benhoussa A., Bazairi H., Jonathan R. et al. (2019). Biomonitoring environmental status in semi-enclosed coastal ecosystems using Zostera noltei meadows. Ecological Indicators. 104:776-793.

Cherkaoui I, Lamrani M (2007) Caractérisation ornithologique des habitats naturels de la lagune de Merja Zerga (Maroc). Ostrich 78(2): 533-540. 
Chiffoleau J.F., Truquet I., (1994). Nouvelles méthodes de dosage de quelques métaux traces dans les sédiments et les matières en suspension. Ifremer. 8-94.

Damek-Poprawa M, Sawicka-Kapusta K. (2003). Damage of the liver, kidney and testis with reference to burden of heavy metals in yellow-necked mice from areas around steel works and zinc smelters in Poland. Toxicology. 186: 1-10.

Ding A.J., Fu C.B., Yang X.Q., Sun J.N., Petäjä T., Kerminen V.M., T. Wang T. and al. (2013). Intense atmospheric pollution modifies weather: a case of mixed biomass burning with fossil fuel combustion pollution in eastern China. Atmos. Chem. Phys. 13: 10545-10554.

Dragun Z., Roje V., Mikac N. and Raspor B., (2009). Preliminary assessment of total dissolved trace metal concentrations in Sava River water. Environ MonitAssess. 159:99-110.

ElAbidi A., Idrissi L., Taleb H., Azizi A., Mameli O. \& Melis P., (2000). The impact of lead pollution on the environment of Rabat-Salé (Morocco). Annali di Chimica, 90 (11-12): 695-702.

Farag M., Hagag M., Saber A., Fayz A. (2012). Contamination of Cows Milk by Heavy Metal in Egypt. Bull Environ Contam Toxicol. 88:611-613.

Fritsch C., Giraudoux P., Coeurdassier M., Douay F., et al, 2010. Spatial distribution of metals in smelterimpacted soils of woody habitats: influence of landscape and soil properties, and risk for wildlife. Chemosphere, 81 (2):141-155.

Garcia-Sevillano M.A, Garcia-Berrera T., Abril N., Pueyo C., Lopez-Barea J. \& Gomez-Ariza J.L. (2014). Omics technologies and their applications to evaluate metal toxicity in mice M.spretus as a bioindicator. Journal of proteomics. (104):4-23.

Gašparík J., Binkowski L., Jahnátek A., Šmehýl P., Massanyi P. and al. (2016). Levels of Metals in Kidney, Liver, and Muscle Tissue and their Influence on the Fitness for the Consumption of Wild Boar from Western Slovakia. Biol Trace ElemRes. 177(2): 258-266.

Gdula-Argasinska J., Dabrowski Z., Witkowska-Pelc E., Kartarzyna Sawicka-Kapusta K., (2005). Heavy metal content and histopathology of the tissues of the Yellow-Necked mice (Apodemus flavicollis) and Bank Voles (Clethrionomys glareolus) as an exposure indicator of environmental pollution in Malopolska Province. Chemia. I Inzynieria Ekologiczna. 12(11): 1213-1220.

Ghaderi A.A., Abduli M.A., Karbassi A.R., Nasrabadi T. and Khajeh M. (2012).Evaluating the Effects of Fertilizers on Bioavailable Metallic Pollution of soils, Case study of Sistan farms, Iran. Int. J. Environ. Res., 6(2): 565-570.

Guey-Shin S., Bai-You C., Chi-Ting C., Pei-Hsuan Y., andTsun-Kuo C. (2011). Applying Factor Analysis Combined with Kriging and Information Entropy Theory for Mapping and Evaluating the Stability of Ground water Quality Variation in Taiwan. Int. J. Environ. Res. Public Health, 8: 1084-1109. 
leradi L.A, Zima J., Allegra F., Kotlanova E., Campanella L., et al. (2003). Evaluation of genotoxic damage in wild rodents from a polluted area in the Czech Republic. Folia Zool. 52(1): 57-66.

Jarić I., Višnjić-Jeftić Z., Cvijanović G., Gačić Z., Jovanović L., Skorić S., Lenhardt M., (2011). Determination of differential heavy metal and trace element accumulation in liver, gills, intestine and muscle of sterlet (Acipenserruthenus) from the Danube River in Serbia by ICP-OES. Microchemical Journal. 98: 77-81.

Kargar M., Khorasani NA., Karami M., Rafiee GH. \& Naseh R. (2012). An investigation on As, Cd, Mo and Cu contents of soils surrounding the Meyduk tailing dam. Int. J Environ. Res. 6(1): 173-184.

Kljakovic-Gaspic Z., Ujevic I. \& Baric A. (2002). The Mediterranean blue mussel as an environmental indicator of metal pollution in the coastal area of Eastern Adriatic. Fresenium Environmental Bulletin. 11(9):620-625.

Koukal B., Dominik J., Vignati D., Arpagaus P., Santiago S., Ouddane B., and Benaabidate L. (2004) Assessment of water quality and toxicity of polluted Rivers Fez and Sebou in the region of Fez (Morocco). Environ Pollut., 131: 163-172.

Lai HY, Hseu ZY, Chen TC, Chen BC, Guo HY, Chen ZS. (2010b). Health risk-based assessment and management of heavy metals-contaminated soil sites in Taiwan. International Journal of EnvironmentalResearch\& Public Health. 7: 3595-3614.

Lee C.S.L., Li X.D., Zhang G., Li J., Ding A., Tao X. (2007). Heavy metals znd Pb isotopic composition of aerosols in urban and suburban areas of Hong Kong and Guangzhou, South China-Evidence of the longrange transport of air contaminants. Atmospheric Environment, 41(2):432-447.

Lopes P.A., Viegas-Crespo A.M., Nunes A.C., Pinheiro T., Marques C., et al. (2002). Influence of age, sex, and sexual activity on trace element levels and antioxidant enzyme activities in field mice (Apodemus sylvaticus and Mus spretus). Biological Trace Element Research, 85: 227,239.

Maanan M., Zourarah B., Sahabi M., Maanan M., Le Roy P., Mehdi K., Salhi F. (2015). Environmental risk assessment of the Moroccan Atlantic continental shelf: The role of the industrial and urban area. Sciences of Total Environment. 511: 407-415.

Marques C.C., Sanchez-Chardi A., Gabriel S., Mathias M.D.L. et al. (2007). How does the greater whitetoothed shrew, Crocidura russula, responds to long-term heavy metal contamination? - A case study. Science of The Total Environment. 376(1-3):128-33.

Metcheva R., S. Teodorova, and M. Topashka-Ancheva. (2002). A comparative analysis of the heavy metal loading of small mammals in different regions of Bulgaria I: monitoring points and bioaccumulation features. Ecotoxicology and Environmental Safety, 54 (2003) 176-187. 
Mhamdi Alaoui A., Choura M., Maanan M., Zourarah B., Robin M., Conceicao M.F., Andrade C., Khalid M., Carruesco C. (2010). Metal fluxes to the sediments of the Moulay Bousselham lagoon, Morocco. Environ EarthSci. 61:275-286.

Mzoughi N. and Chouba L. (2012). Heavy Metals and PAH Assessment Based on Mussel Caging in the North Coast of Tunisia (Mediterranean Sea). Int. J. Environ. Res.,6 (1), 109-118.

Nasrabadi T., Nabi Bidhendi G. R., Karbassi A. R. and Mehrdadi N., (2010). Partitioning of metals in sediments of the Haraz River (Southern Caspian Sea basin), Environmental Earth Sciences, 59, 11111117.

Ogundiran M.B. and Osibanjo O., (2008). Heavy metal concentrations in soils and accumulation in plants growing in a deserted slag dumpsite in Nigeria. African Journal of Biotechnology. 7(17): 3053-3060.

Okuku, E.O. and Peter, H. K., (2012). Choose of Heavy Metals Pollution Biomonitors: A Critic of the Method that uses Sediments total Metals Concentration as the Benchmark. Int. J.Environ. Res., 6 (1), $313-322$.

ORMVAG (2007). Contrôle de l'impact des engrais et des pesticides sur l'environnement du bassin du Sebou SCET-Maroc. HTE. 138: 30. Rampaud M., (1988). Les rongeurs d'Afrique du Nord. Notes de cours. Section de lutte contre les vertébrés, ICE Agrochemicals, Fernhurst, Haslemere, Surrey GU27 3JE, GrandeBretagne, $30 \mathrm{p}$.

ORMVAG. "Eude de la faisabilité de l'aménagement hydro-agricole de la zone côtière de la troisième tranche d'irrigation du Gharb. Mission 1: Diagnostic de la situation actuelle, 2010 " Doc n¹367 -S1231 -10 cMarché n53/2009/DAM Edition défınitive: décembre, 2010 Maroc.

Pesce Stéphane, (2006). Effets des pesticides sur l'activité et la diversité des communautés microbiennes d’un milieu lotique récepteur.Etudes in situ et expérimentales. Thèse de doctorat. Université Blaise Pascal, Clermont II, 271p.

PrevendarCrnić A., Šuran J., CiprišMadunić H. and Božić F., (2015). Cadmium concentrations in the tissues of young wild boar (Sus scrofa L.) from Moslavina and Slavonia in lowland Croatia. VETERINARSKI ARHIV. 85 (3): 323-334.

Qninba A., Benhoussa A., El Agbani M.A., Thévenot M., et al (2006). Etude phénologique et variabilité annuelle d'abondance des charadriidés (Aves, charadrii) dans un site Ramsar du Maroc: La Merja Zerga. Bulletin de I'Institut Scientifique, section Sciences de la Vie, n²8, 35-47.

Quina A.S., Durao A.F., Munoz F., Ventura J., et al. (2019). Population effects of heavy metal pollution in wild Algerian mice (Mus spretus). Ecotoxicology and Environmental Safety.171: 414:424.

Rautio A., Kunnasranta M., Valtonen A., Ikonen M., Hyva“rinen H., Holopainen I.J., Kukkonen J.V.K., (2010). Sex, Age, and Tissue Specific Accumulation of Eight Metals, Arsenic, and Selenium in the European Hedgehog (Erinaceuseuropaeus). Arch Environ ContamToxicol. 59:642-651. 
Sambo F., Haruna M., Idris S., Mohd S. \& Nasir A. (2014). Assessment of heavy metals in water and fish from Ibrahim Adamu Lake, Jigawa, Nigeria. Trends in Applied Sciences Research. 9:603-606.

Sanchez-Chardi A. and Nadal J., (2007). Bioaccumulation of metals and effects of landfill pollution in small mammals. Part I. The greater white-toothed shrew, Crocidura russula. Chemosphere. 68: 703-711.

Serbaji M.M., Azri C. and Medhioub K., (2012).Anthropogenic Contributions to Heavy Metal Distributions in the Surface and Sub-surface Sediments of the Northern Coast of Sfax, Tunisia. Int. J. Environ. Res. 6 (3): 613-626.

Stankovic S., Kalaba P., Stankovic R., 2014. Biota as toxic metal indicators. Environ Chem Lett (2014) 12:63-84.

Sunjog K., Gacic Z., Kolarevic S., Visnji Z., Lenhardt M. and \& al. (2012). Heavy Metal Accumulation and the Genotoxicity in Barbel (Barbusbarbus) as Indicators of the Danube River Pollution. The Scientific World Journal. Vol 2012.

Tête N., Afonso E., Crini N., Drouhot S., Prudent A.S. and Scheifler R., (2014). Hair as a non-lethal tool for risk assessment: do the concentrations of cadmium and lead in the hair of wood mice (Apodemus sylvaticus) reflect internal concentrations? Ecotoxicology and Environmental Safety . 108(233-241).

Tête N., Durfort M., Rieffel D., Scheifler R., Sánchez-Chardi A., (2014). Histopathology related to cadmium and lead bioaccumulation in chronically exposed wood mice, Apodemus sylvaticus, around a former smelter. Science of the Total Environment. 481, 167-177.

Tifarouine L., Benhoussa A., Bazairi H. et al. (2018). Assessing the use of small mammalians as bioindicators in northern Morocco (Oued Siad/Jbel Moussa) using heavy metal accumulation. J. Mater. Environ. Sci. 9(3):834-840.

Tifarouine L., Benhoussa A., Bouaabid B., Rguibi Idrissi H. et al. (2019). Influence of age on the bioaccumulation of heavy metals in Apodemus sylvaticus at Merja Zerga lagoon, Morocco. Saudi Journal of biological Sciences. 26(7): 1682, 1688.

Touhami F., Bazairi H., Badaoui B. \& Benhoussa A. (2018). The impact of wader predation on benthic macrofauna in merja Zerga lagoon, Morocco: an exclosure experiment. Wader Study, 124(3):225-237.

Touhami F., Bazairi H., Badaoui B., Benhoussa A. (2018). Vertical distribution of benthic macrofauna in intertidal habitats frequented by Shorebirds at Merja Zerga Lagoon. Thalassas. 34(3):255-265.

Udroiu I., Cristaldi M., leradi L.A., Tanzarella C. \& Moreno S. (2008). Biomonitoring of Danona national park using the Algerian mouse (Mus spretus) as a sentinel species. Fresenius Environmental Bulletin. 17(9b): 1519-1525. 
Wang Q., Sun Y., Xu W., Du W., Zhou L., Tang G. et al, (2018). Vertically resolved characteristics of air pollution during two severe winter haze episodes in urban Beijing, China. Atmos. Chem. Phys. 18(4):24952509.

Wariaghli F., Tilghman-Sibille A., ElAbidi A., Fekhaoui M., and Yahyaoui A., (2013). Anguilla anguilla L.: Evaluation of the degree of heavy metal contamination in the Sebou estuary and in Moulay Bousselham lagoon reserve (Morocco). International Journal of Aquatic Science. 4(2): 69-82.

Xiaoyu Li.,Lijuan L.,Yugang W., Geping L., Xi C., Xiaoliang Y., Bin G., and Xingyuan H. (2012). Integrated Assessment of Heavy Metal Contamination in Sediments from a Coastal Industrial Basin, NE China. PLoS One. 7(6): e39690.

Yorulmaz B., Yılmaz F. and Genç T. O. (2015). Heavy Metal Concentrations in European Eel (Anguilla anguilla L., 1758) from Köyceğiz-Dalyan Lagoon System. Fres. Environ. Bull. 24(5): 1607-1613.

Ziętara J., Wierzbowska I.A., Gdula-Argasińska J., Gajda A., Laskowski R., (2018). Concentrations of cadmium and lead, but not zinc, are higher in red fox tissues than in rodents pollution gradient study in the Malopolska province (Poland). Environ Sci Pollut Res. 26(5): 4961-4974.

\section{Tables}

Table 1: Distribution of captured specimens by age and sex (In brackets: males - females)

\begin{tabular}{|c|ccc|}
\hline Site & \multicolumn{2}{|c|}{ Age } & Total \\
& Juveniles & Adults & \\
& & & \\
\hline Merja Zerga & 18 & 21 & 39 \\
& $(14-4)$ & $(11,10)$ & $(25,14)$ \\
\hline Dayet Erroumi & 7 & 25 & 32 \\
& $(4,3)$ & $(8,17)$ & $(12,20)$ \\
\hline
\end{tabular}


Table 2: Student's t-test results for variation in tissue-specific metal concentrations for each site and comparison between the two sexes

\begin{tabular}{|c|c|c|c|c|c|c|c|c|}
\hline \multirow[b]{2}{*}{ Organs/Metals } & \multicolumn{2}{|c|}{ Merja Zerga $(\delta q)$} & \multicolumn{2}{|c|}{ Dayet Erroumi $(\hat{\jmath}+)$} & \multicolumn{2}{|c|}{$\partial^{\lambda}$ Meria Z. Oे Dayet E. } & \multicolumn{2}{|c|}{$q_{\text {Meria Zan }}$ + Davet E. } \\
\hline & $\mathrm{t}$ & $\mathrm{p}$ & $\mathrm{t}$ & $\mathrm{p}$ & $\mathrm{t}$ & $\mathrm{p}$ & $\mathrm{t}$ & $\mathrm{p}$ \\
\hline Liver & & & & & & & & \\
\hline $\mathrm{Zn}$ & 0,987 & - & $-3,205$ & $<0,01$ & $-2,757$ & $<0,01$ & $-5,125$ & $<0,001$ \\
\hline $\mathrm{Pb}$ & $-0,590$ & - & $-2,24$ & $<0,05$ & 1,964 & $<0,05$ & 1,042 & - \\
\hline $\mathrm{Cr}$ & 0,805 & - & $-0,661$ & - & 4,844 & $<0,001$ & 1,583 & - \\
\hline $\mathrm{Cu}$ & 0,422 & - & $-1,673$ & - & 6,165 & $<0,001$ & 2,7 & $<0,01$ \\
\hline $\mathrm{Fe}$ & 0,638 & - & $-3,172$ & $<0,01$ & 1,986 & $<0,05$ & $-1,981$ & $<0,05$ \\
\hline Kidney & & & & & & & & \\
\hline $\mathrm{Zn}$ & 1,66 & - & $-3,107$ & $<0,01$ & $-2,786$ & $<0,01$ & $-5,276$ & $<0,001$ \\
\hline $\mathrm{Pb}$ & $-1,196$ & - & $-2,264$ & $<0,05$ & 0,060 & - & $-0,134$ & - \\
\hline $\mathrm{Cr}$ & 1,980 & $<0,05$ & $-1,042$ & - & 3,743 & $<0,001$ & 1,193 & - \\
\hline $\mathrm{Cu}$ & 0,063 & - & $-1,604$ & - & 4,752 & $<0,001$ & 2,058 & $<0,05$ \\
\hline $\mathrm{Fe}$ & 0,409 & - & $-3,603$ & $<0,001$ & 1,564 & - & $-2,914$ & $<0,01$ \\
\hline Heart & & & & & & & & \\
\hline $\mathrm{Zn}$ & 1,324 & - & $-3,003$ & $<0,01$ & $-2,969$ & $<0,01$ & $-5,04$ & $<0,001$ \\
\hline $\mathrm{Pb}$ & 0,018 & - & $-1,622$ & - & $-1,974$ & $<0,05$ & $-2,53$ & $<0,01$ \\
\hline $\mathrm{Cr}$ & 1,484 & - & $-1,186$ & - & 2,229 & $<0,05$ & $-0,016$ & - \\
\hline $\mathrm{Cu}$ & 1,048 & - & $-1,584$ & - & 2,977 & $<0,01$ & 1,189 & - \\
\hline $\mathrm{Fe}$ & 1,081 & - & $-3,423$ & $<0,001$ & 0,858 & - & $-3,805$ & $<0,001$ \\
\hline
\end{tabular}

\section{Figures}

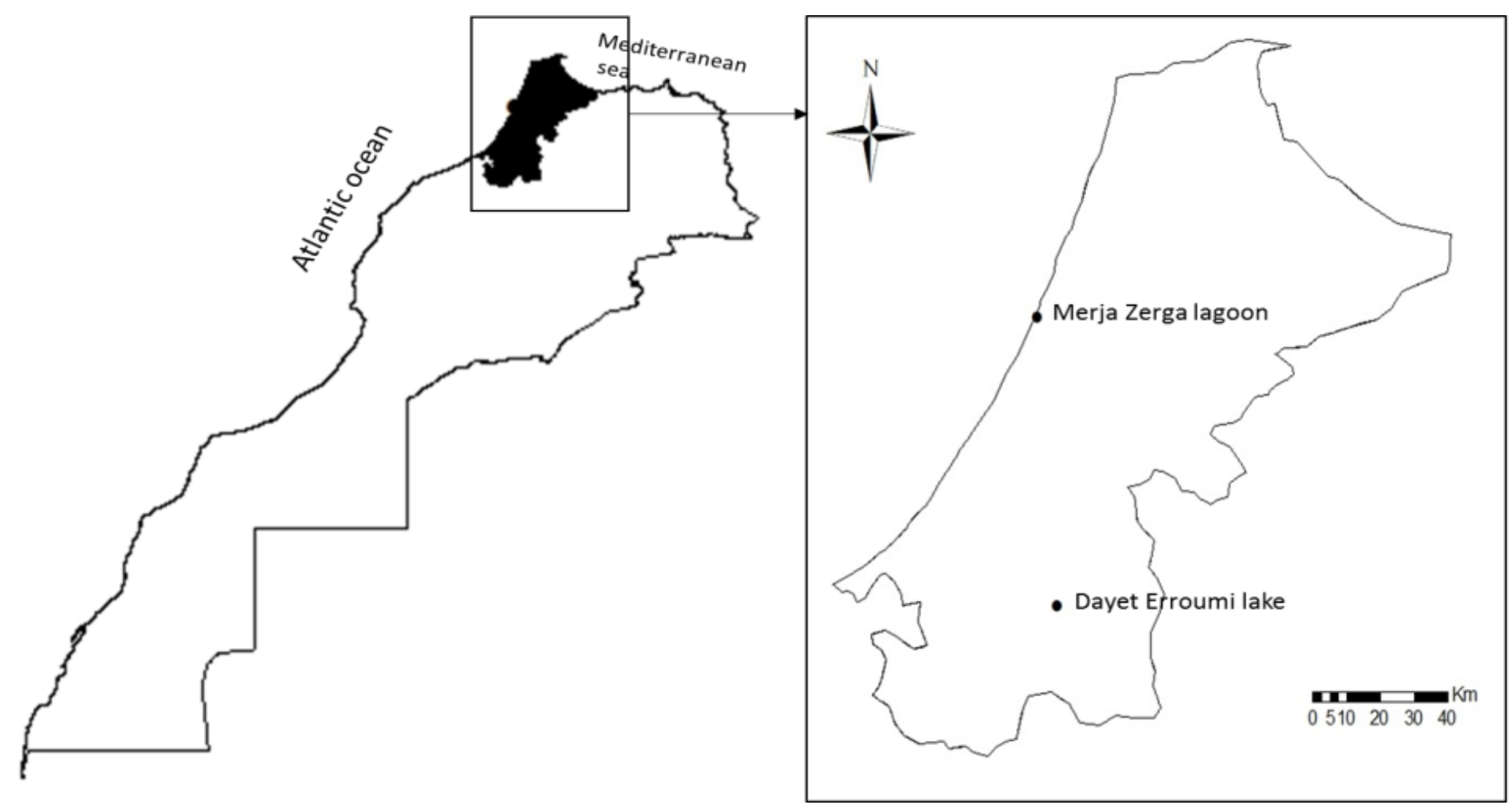

Figure 1 
Localization of the study areas in North of Morocco
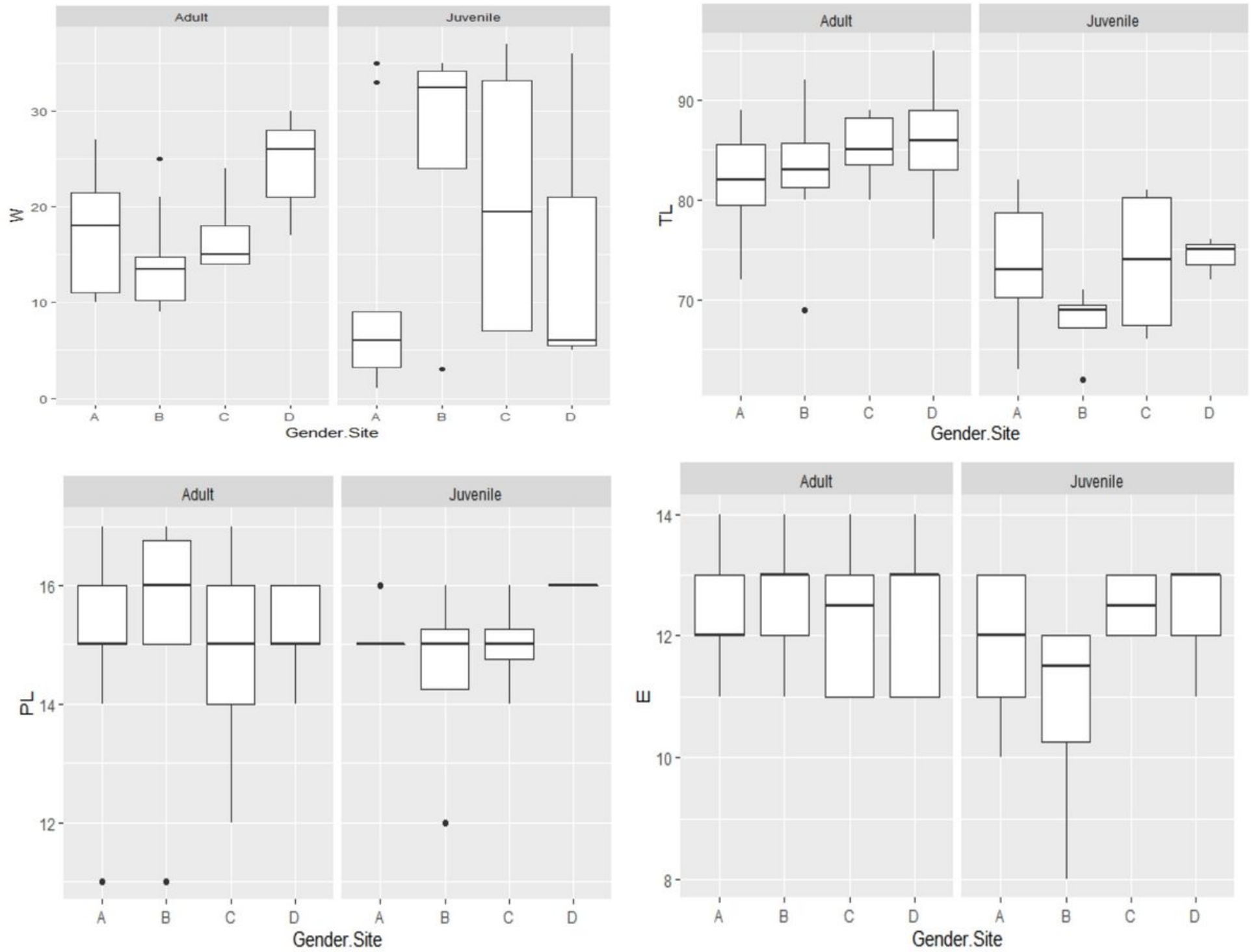

Figure 2

Body measurements (Weight: W, Head-Body Length: TL, Ear length: E, and Posterior Legs length: PL) of Mus sprteus captured in Merja Zerga and Dayet Erroumi (A: Male Merja Zerga and B: Female Merja Zerga; C: Male Dayet Erroumi and D: Female Dayet Erroumi) 

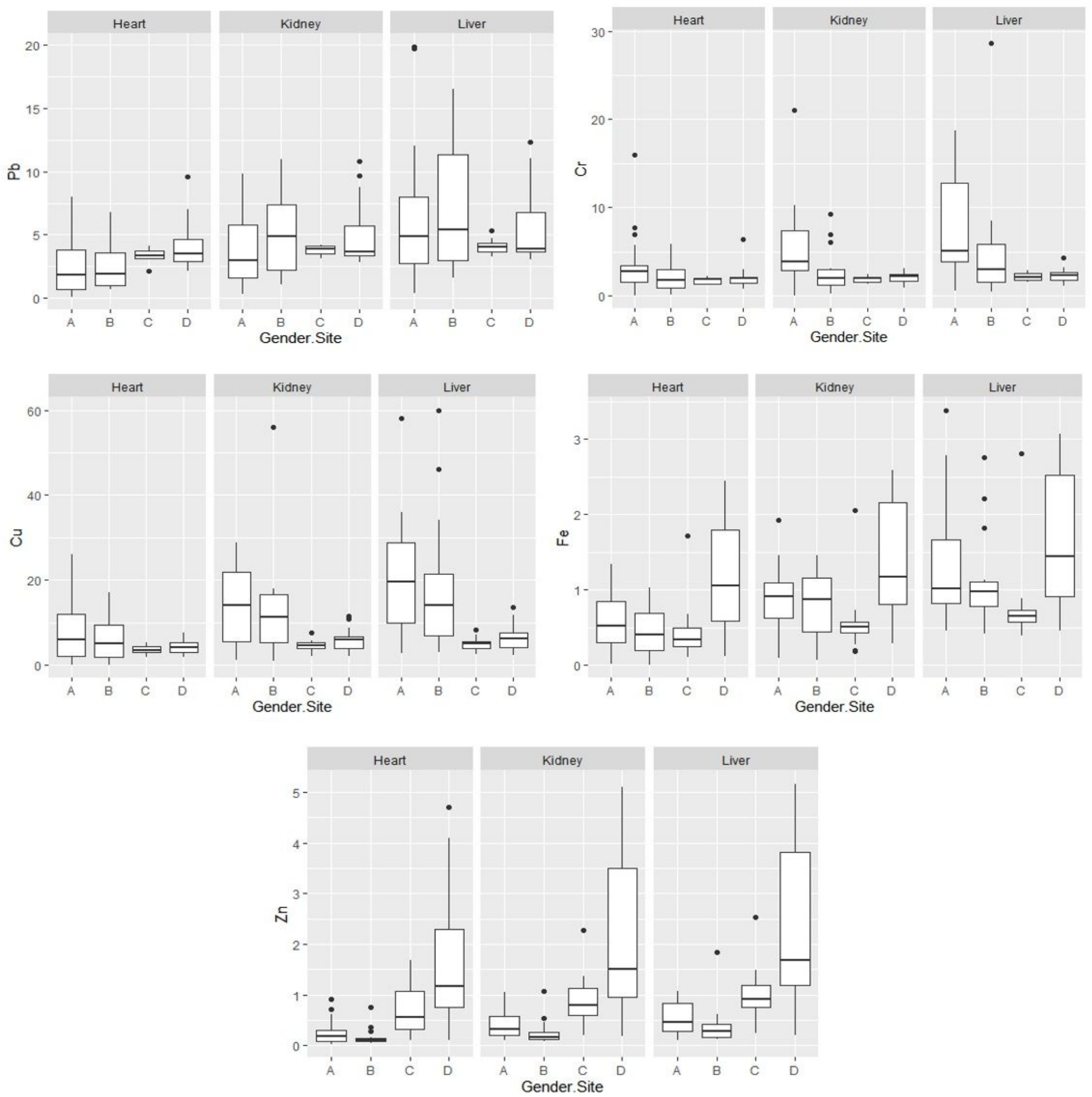

Figure 3

Concentrations of trace elements ( $\mu \mathrm{g} / \mathrm{g}$ ) in the liver, kidney and heart of Mus spretus of Merja Zerga and Dayet Erroumi (A: Male Merja Zerga and B: Female Merja Zerga; C: Male Dayet Erroumi and D: Female Dayet Erroumi) 

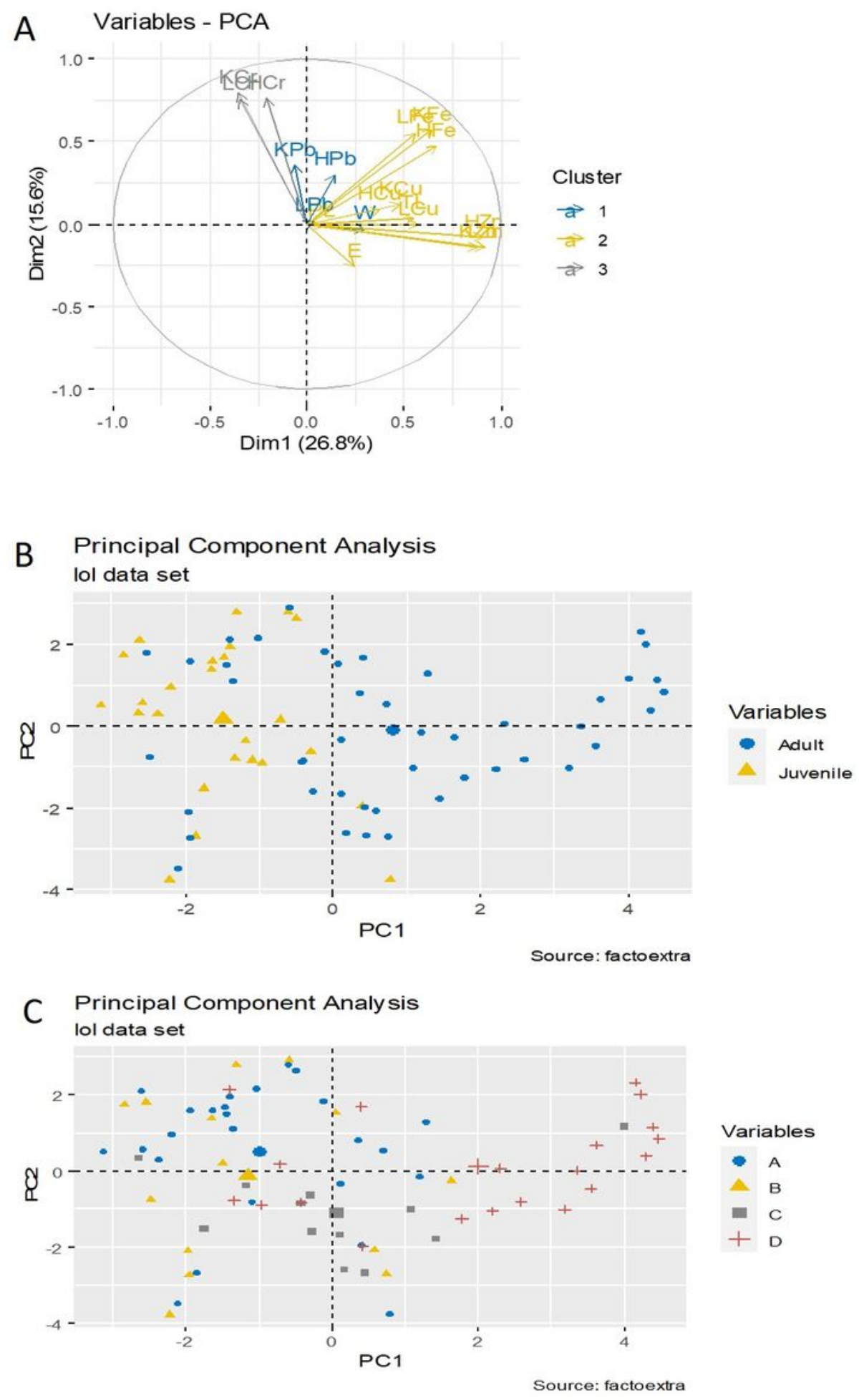

\section{Figure 4}

a: Correlation circle obtained by the analysis in principal components (PCA) of the morphometric variables and the concetrations of HMs in the organs of Mus spretus in the factor space of (F1 and F2) $b$ : Factor loading plots for the first two principal components identified in the PCA of projection of individuals. The colors represent the age categories of the specimens (Adult: blue; Juvenile: mustard yellow) c : Factor loading plots for the first two principal components identified in the PCA of projection of 
individuals. The four colors represent the different groups according to sex and area (Male Merja Zerga: blue; female Merja Zerga: mustard yellow; Male Dayet Erroumi: gray and female Dayet Erroumi: bordeaux red)

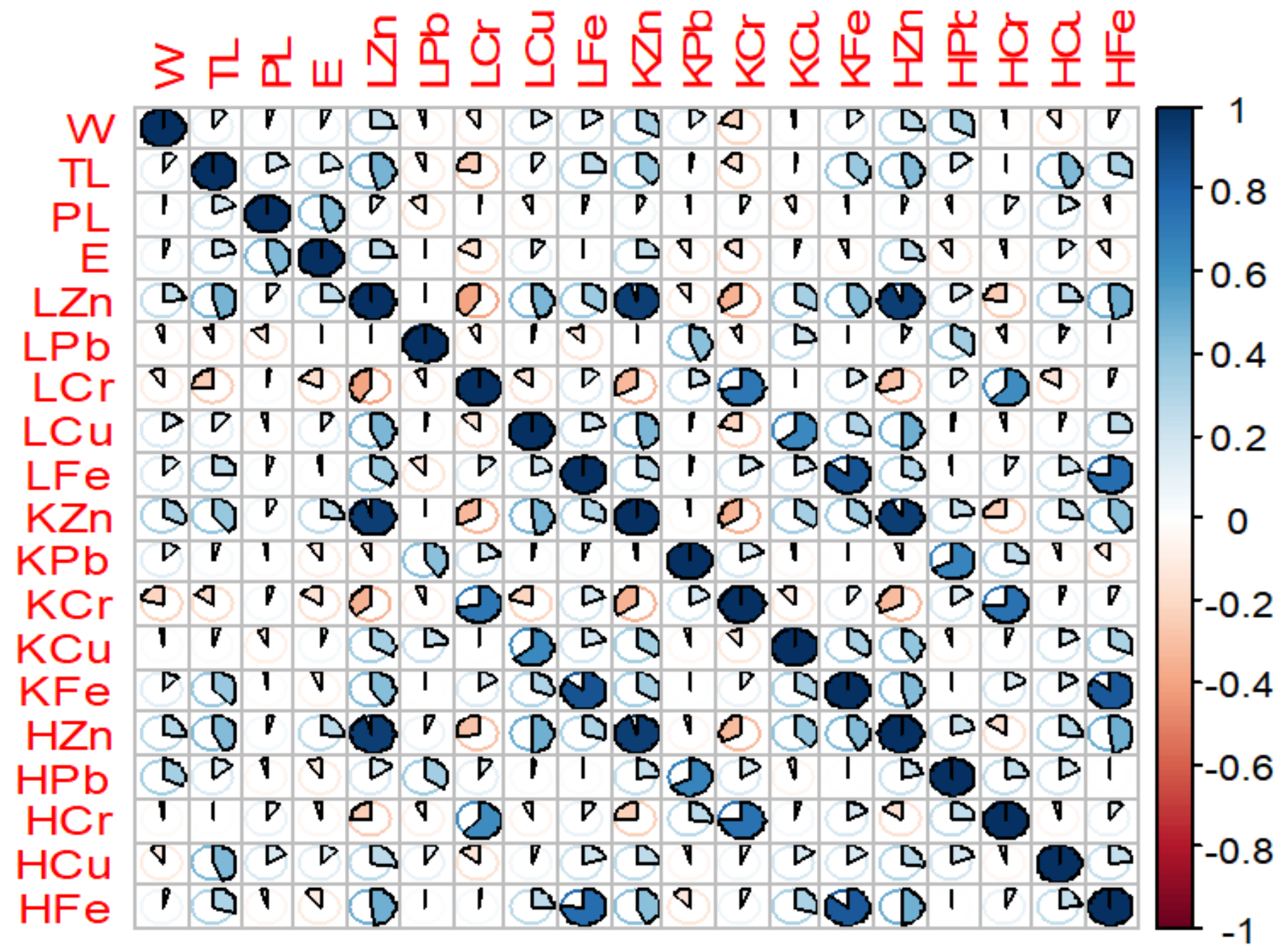

Figure 5

Correlations between the different variables: Morphometric (W, TL, PL, E) and heavy metals in the organs (Liver: LZn, LPb, LCr, LCu, LFe ; Kidney: KZn, KPb, KCr, KCu, KFe ; Heart: HZn, HPb, HCr, HCu, HFe) 